\title{
MUC1* Positive Cells Present
}

National Cancer Institute

\section{Source}

National Cancer Institute. MUC1* Positive Cells Present. NCI Thesaurus. Code C158467.

An indication that the cells in sample have cell surface expression of antibody-detectable amounts of a specific membrane-bound fragment of the mucin-1 protein (MUC1), which results from extramembrane cleavage, has growth factor receptor-like activity and is comprised of the cytoplasmic tail, the transmembrane domain and at least forty-five amino acids of the extracellular domain. 